\title{
UNDERNUTRITION AND BRAIN DEVELOPMENT EFFECT OF LYSINE AND THREONINE SUPPLE- MENTATION ON BRAIN FUNCTION IN MONOZYGOTIC TWINS
}

\author{
Toshio Oiso, Einosuke Tamura, Shoji Kawada, Hiroshi Wako,* \\ Tomiji Hatakeyama,* Keiichi AraI, ${ }^{*}$ and Hirotaka NodA*1 \\ National Institute of Nutrition, Tokyo \\ *Department of Pediatrics, Iwate Medical University, \\ Morioka, Japan
}

(Received December 14, 1972)

\begin{abstract}
This investigation confirmed that undernourished infants and children who were in a state of mild-moderate protein-calorie malnutrition showed significant cognitive growth when their diet was supplemened with lysine-threonine tablets for more than 3 years. In children over 3 years of age a rise in D.Q. might be less pronounced as compared with the cases of children under 3 years of age. Thus it is suggested that nutritional improvement of children in undernourished areas may somehow influence mental development, while it is certain that social, and environmental factors have a very important influence on brain function.
\end{abstract}

Whereas severe malnutrition may lead to intellectual impairment, the direct relationship between moderate malnutrition and intelligence is still unknown. In the last few years much attention has been given to researches concerning the effect of malnutrition on brain function and mental development. Children who have survived undernutrition in early life show poor intellectual development and under certain circumstances an irreversible growth retardation may be seen. From some observations based on animals as well as humans, it is suggested and generally accepted that severe malnutrition in early life may cause irreversible brain damage and prevent the child from attaining its full potential (1-4). In recent years a marked interest has arisen as to whether a chronic subalimentation status, not reaching a severe degree, may modify behavioral and mental capacities of human beings. If the above-mentioned modification or hypothesis is indeed acceptable, human experimental data in infants and children should be obtained.

\footnotetext{
${ }^{1}$ 大礒敏雄，田村盈之輔，河田正治，若生 宏，畠山富而，新井恵一，野田寛隆
} 
However, it might still be difficult to prove this hypothesis with regard to mental and motor retardation under the mild-moderate state of malnutrition with the available experimental data.

In an attempt to clarify the problem, pairs of monozygotic twins in an undernourished area of Tohoku district in Japan were subjected to experiments and the question of whether a greater increment may occur in cognitive growth among the monozygotic twins who were supplemented with lysine and threonine as compared with the control twins was examined. The areas where the subjects were selected belong to one of the lowest socioeconomic areas showing the highest infant mortality in Japan, although in recent years these areas have been developing quite rapidly as the result of nutritional and economic improvement.

A preliminary nutrition survey of the children in the areas chosen was carried out in order to investigate the background of the nutritional status of the children in these undernourished areas and their socioeconomic conditions. In addition to physical measurements, red blood cell count, hemoglobin and serum protein levels, plasma amino acid ratio, and the dietary intake of children were investigated. Investigating the effect of lysine and threonine supplementation on the plasma amino acid ratio, it was revealed that the mean amino acid ratio decreased from 2.2 to 1.9 with supplementation of the amino acids (5). This indicates that the children in the experimental areas are in a mild-moderate state of protein malnutrition.

\section{MATERIALS AND METHODS}

A comparative longitudinal study of physical and intellectual development of monozygotic twins, 2 to 3 years of age, was performed for about 1,300 days from 1967 to 1971 . Cases were selected from the undernourished areas of twins younger than 3 years, case of twins 3 years and 6 months old. The twins from these areas had a low intake of protein and fat. Rice occupied about $85 \%$ of all dietary intake. A small amount of fish and eggs was taken only twice a week. The survey of the actual food intake in the 6 pairs of twins selected was very important in evaluating their nutritional status, but we could not conduct a detailed dietary survey because of psychlological influence of the survey on the twins and their parents. However a dietary survey was performed on children in these areas, whose living conditions are similar to those of the subjects. An outline of the results is summarized in Table 1.

Each pair of the monozygotic subjects lived at home and kept to their normal routine except that one child of each pair received 2 tablets daily, one containing $0.1 \mathrm{~g}$ of lysine and the other $0.05 \mathrm{~g}$ of threonine at morning and evening mealtimes respectively, the other child receiving placebo tablets at the same times. The children were weighed and measured regularly. Tests for perception, kinethesis, 
Table 1. Food Intake in 3-year-old children of undernourished areas and control area.

(1967)

\begin{tabular}{|c|c|c|c|c|c|c|c|c|c|c|c|}
\hline & \multirow{2}{*}{ Subject. } & \multirow{2}{*}{ Cal. } & \multirow{2}{*}{$\begin{array}{c}\text { Prot. } \\
\text { (animal) } \\
\text { (g) }\end{array}$} & \multirow{2}{*}{$\begin{array}{l}\text { Fat } \\
(\mathrm{g})\end{array}$} & \multirow{2}{*}{$\begin{array}{c}\text { Carb. } \\
\text { (g) }\end{array}$} & \multirow{2}{*}{$\begin{array}{r}\mathrm{Ca} \\
(\mathrm{mg}) \\
\end{array}$} & \multirow{2}{*}{$\begin{array}{c}\mathrm{Fe} \\
(\mathrm{mg})\end{array}$} & \multicolumn{4}{|c|}{ Vitamins (IU, mg) } \\
\hline & & & & & & & & A & $\mathrm{B}_{1}$ & $\mathrm{~B}_{2}$ & $\mathrm{C}$ \\
\hline I.D. ${ }^{\mathrm{a}}$, & 15 & 1067 & $\begin{array}{l}33 \\
(7)\end{array}$ & 10 & 214 & 116 & 8.0 & 391 & 0.24 & 0.21 & 66 \\
\hline T.D. ${ }^{a}$ & 32 & 1182 & $\begin{array}{r}39 \\
(15)\end{array}$ & 24 & 198 & 365 & 7.8 & 463 & 0.43 & 0.56 & 49 \\
\hline H.D. ${ }^{a}$ & 12 & 947 & $\begin{array}{r}32.6 \\
(12.7)\end{array}$ & 17 & 165 & 163 & 8.8 & 391 & 0.26 & 0.29 & 66 \\
\hline Control D. ${ }^{\mathrm{b}}$ & b 15 & 1444 & $\begin{array}{r}55 \\
(32)\end{array}$ & 50 & 187 & 584 & 8.2 & 1286 & 0.71 & 0.90 & 53 \\
\hline
\end{tabular}

a I.D. T.D. H.D.: Experimental districs

b Control D.: Control district (Morioka City)

Table 2. Progress of body weight and height in twins.

\begin{tabular}{|c|c|c|c|c|c|c|c|c|c|}
\hline \multirow[t]{2}{*}{ Case } & & \multirow[t]{2}{*}{ Sex } & \multirow{2}{*}{$\begin{array}{c}\text { Age } \\
\text { (Yr: mo) }\end{array}$} & \multicolumn{2}{|c|}{ Before suppl. } & \multicolumn{2}{|c|}{$\begin{array}{c}\text { After suppl. } \\
1300 \text { days }\end{array}$} & \multicolumn{2}{|c|}{ Increase of growth } \\
\hline & & & & $\begin{array}{c}\text { Weight } \\
\text { (kg) }\end{array}$ & $\begin{array}{l}\text { Height } \\
(\mathrm{cm})\end{array}$ & $\begin{array}{c}\text { Weight } \\
\text { (kg) }\end{array}$ & $\begin{array}{l}\text { Height } \\
(\mathrm{cm})\end{array}$ & $\begin{array}{c}\text { Weight } \\
\text { (kg) }\end{array}$ & $\begin{array}{l}\text { Height } \\
(\mathrm{cm})\end{array}$ \\
\hline \multirow[t]{2}{*}{1} & Expt. & $F$ & $1: 4$ & 9.7 & 79.8 & 17.5 & 104.0 & 7.8 & 24.2 \\
\hline & Cont. & $\mathrm{F}$ & $1: 4$ & 9.8 & 80.0 & 17.0 & 104.0 & 7.2 & 24.0 \\
\hline \multirow[t]{2}{*}{2} & Expt. & $F$ & $1: 1$ & 10.0 & 83.0 & 19.0 & 112.0 & 9.0 & 29.0 \\
\hline & Cont. & $\mathrm{F}$ & $1: 1$ & 10.1 & 83.9 & 18.0 & 110.0 & 7.9 & 26.1 \\
\hline \multirow[t]{2}{*}{3} & Expt. & $\mathrm{F}$ & $2: 0$ & 12.0 & 89.9 & 19.5 & 105.5 & 7.5 & 15.6 \\
\hline & Cont. & $\mathrm{F}$ & $2: 0$ & 12.0 & 91.5 & 18.0 & 103.8 & 6.0 & 12.3 \\
\hline \multirow[t]{2}{*}{4} & Expt. & F & $2: 3$ & 11.8 & 85.4 & 15.0 & 102.0 & 3.2 & 16.6 \\
\hline & Cont. & $\mathbf{F}$ & $2: 3$ & 12.4 & 87.0 & 15.0 & 103.0 & 2.6 & 16.0 \\
\hline \multirow[t]{2}{*}{5} & Expt. & $\mathbf{M}$ & $2: 6$ & 12.1 & 86.9 & 16.0 & 102.2 & 3.9 & 15.3 \\
\hline & Cont. & $\mathbf{M}$ & $2: 6$ & 13.8 & 89.8 & 16.0 & 102.3 & 2.2 & 12.5 \\
\hline \multirow[t]{2}{*}{6} & Expt. & $\mathbf{M}$ & $3: 6$ & 13.7 & 95.6 & 20.0 & 115.5 & 6.3 & 19.9 \\
\hline & Cont. & $\mathbf{M}$ & $3: 6$ & 14.0 & 96.8 & 20.5 & 116.5 & 6.5 & 19.7 \\
\hline
\end{tabular}

Expt., experimental; Cont., control.

sociality, learning, manipulatory capacity and psychic function were performed at the beginning of the experiment which started at the ages indicated in Table 2. D.Q. was calculated from these 6 items estimated by the method of UsHIJIMA et al. (6) currently used in Japan. The same tests were conducted after 300 days, 540 days, 780 days, 920 days and 1,300 days. And Suzuki-Binet's intelligence test (7) whose yield was I.Q. was conducted after 920 and 1,300 days. The mothers could designate which child would be the experimental and which the control child in the pair of twins, and the experimental children of the pairs were generally inferior in growth and D.Q. as compared with the control children (Tables 2 and 3) and were supplemented with the lysine-threonine tablets daily for about 43 months. The group is indicated as the experimental group in the tables. 
Table 3. Developmental quotient (D.Q.) in six pairs of twins: before experiment.

\begin{tabular}{|c|c|c|c|c|c|c|}
\hline Case & Date of birth & $\begin{array}{l}\text { Body weight } \\
\text { at birth (g) }\end{array}$ & Sex & $\begin{array}{c}\text { Age } \\
(\text { Yr:mo) }\end{array}$ & $\underset{\text { (expt.) }}{\text { D.Q. }}$ & $\begin{array}{c}\text { D.Q. } \\
\text { (cont.) }\end{array}$ \\
\hline \multirow[t]{2}{*}{1} & Oct. 13,1966 & 2,730 & F & $1: 4$ & 125 & \\
\hline & & 2,800 & $\mathrm{~F}$ & & & 131 \\
\hline \multirow[t]{2}{*}{2} & Jul. 12, 1966 & 2,550 & F & $1: 1$ & 79 & \\
\hline & & 2,250 & $\mathrm{~F}$ & & & 81 \\
\hline \multirow[t]{2}{*}{3} & Nov. 12,1965 & 1,900 & $\mathrm{~F}$ & $2: 0$ & 93 & \\
\hline & & 2,480 & $\mathrm{~F}$ & & & 96 \\
\hline \multirow[t]{2}{*}{4} & Nov. 20, 1965 & 2,000 & F & $2: 3$ & 77 & \\
\hline & & 2,000 & $\mathrm{~F}$ & & & 84 \\
\hline \multirow[t]{2}{*}{5} & Jun, 10, 1965 & 2,450 & $\mathbf{M}$ & $2: 6$ & 67 & \\
\hline & & 2,900 & $\mathbf{M}$ & & & 69 \\
\hline \multirow[t]{2}{*}{6} & Jul. 18, 1964 & 2,510 & $\mathbf{M}$ & $3: 6$ & 81 & \\
\hline & & 2,580 & $\mathbf{M}$ & & & 86 \\
\hline
\end{tabular}

\section{RESULTS*}

The results showed that the children concurrently given the same amount of placebo tablets showed a tendency of decline in increase of body weight and height compared with those receiving lysine-threonine supplementation (Table 2). The

Table 4. D.Q. and I.Q. Scores of twins in each test.

\begin{tabular}{llrrrrrr}
\hline $\begin{array}{c}\text { Monozygotic } \\
\text { Twins }\end{array}$ & & $\begin{array}{c}\text { Before } \\
\text { Exp. (I) } \\
\text { D.Q. }\end{array}$ & $\begin{array}{c}\text { 300 days } \\
\text { D.Q. }\end{array}$ & $\begin{array}{c}\text { 540 days } \\
\text { D.Q. }\end{array}$ & $\begin{array}{c}\text { 780 days } \\
\text { D.Q. }\end{array}$ & $\begin{array}{c}\text { (IV) } \\
\text { D.Q. (I.Q.) }\end{array}$ & $\begin{array}{c}\text { (VI) } \\
\text { D.00 days } \\
\text { (I.Q.) }\end{array}$ \\
\hline Case 1 & Exp. & 125 & 139 & 149 & $125^{\mathrm{a}}$ & $135(140)$ & $(140)$ \\
$(1 \mathrm{y}, 4 \mathrm{~m})$ & Contr. & 131 & 137 & 135 & $117^{\mathrm{a}}$ & $119(119)$ & $(123)$ \\
Case 2 & Exp. & 79 & 106 & 112 & $106^{\mathrm{a}}$ & $101(96)$ & $(96)$ \\
$(1 \mathrm{y}, 1 \mathrm{~m})$ & Contr. & 81 & 87 & 100 & $100^{\mathrm{a}}$ & $92(92)$ & $(92)$ \\
Case 3 & Exp. & 93 & 105 & 120 & $103^{\mathrm{a}}$ & $106(105)$ & $(106)$ \\
$(2 \mathrm{y}, 1 \mathrm{~m})$ & Contr. & 96 & 94 & 115 & $100^{\mathrm{a}}$ & $100(99)$ & $(103)$ \\
Case 4 & Exp. & 77 & 94 & $-\mathrm{b}$ & $101^{\mathrm{a}}$ & $123(124)$ & $(124)$ \\
$(2 \mathrm{y}, 3 \mathrm{~m})$ & Contr. & 84 & 86 & - & $91^{\mathrm{a}}$ & $115(101)$ & $(118)$ \\
Case 5 & Exp. & 67 & 85 & 101 & $101^{\mathrm{a}}$ & $105(105)$ & $(103)$ \\
$(2 \mathrm{y}, 6 \mathrm{~m})$ & Contr. & 69 & 81 & 87 & $87^{\mathrm{a}}$ & $99(89)$ & $(82)$ \\
Case 6 & Exp. & 81 & 82 & 81 & $97^{\mathrm{a}}$ & $108(108)$ & $(107)$ \\
$(3 \mathrm{y}, 6 \mathrm{~m})$ & Contr. & 86 & 88 & 87 & $87^{\mathrm{a}}$ & $108(101)$ & $(101)$ \\
\hline
\end{tabular}

a Decrease of D.Q. in test IV was due to the stress caused by taking movie film.

$b$ Test could not be performed due to toothache of experimental children.

c A statistical analysis of the data in this table shows that there was a significant difference between the supplemented group and the control group in the rise of D.Q. The mean value $(\bar{x})$ of the differences between the supplemented and control groups in the rise of D.Q. from the first test to the fifth test is $11.67(P<0.01)$.

* The following abbreviations are used: D.Q., development quotient; I.Q., intelligence quotient. 


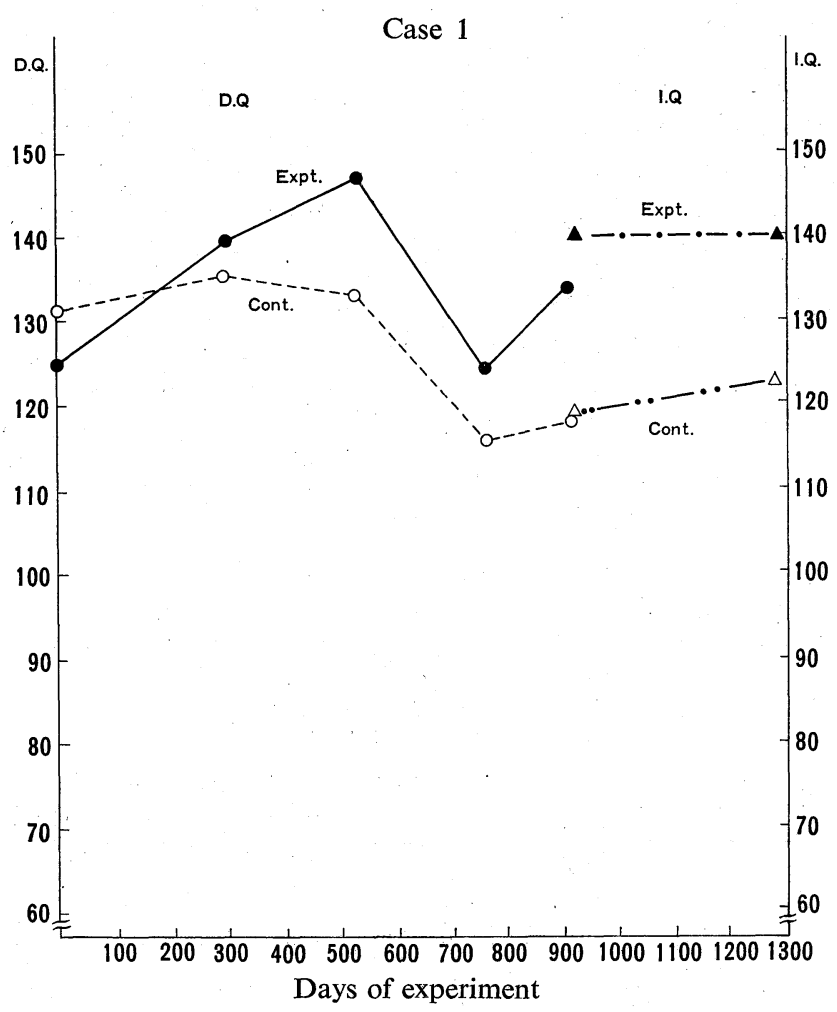

Fig. 1. Changes in developmental quotient (D.Q.) and intelligence quotient (I.Q.) in a pair of twins during L-lysine and threonine supplementation (Case 1). 우 Age 1yr: 4 mo-7 day

same tests were performed several times during the 1,300-day experimental period. These tests showed a significant rise in D.Q. in the lysine-threonine administered twins, though each case showed its own characteristic tendencies (Table 4 and Fig. 1).

Figure 1 indicates an example of data obtained by the D.Q. measurement with the subject Case 1 , who was 1 year and 4 months old. The D.Q. of the experimental child was 125 and the control twin 131 at the beginning of the experiments (first test in Table 4). The second test was performed after 300 days, the third test after 540 days, the fourth test after 780 days, the fifth test after 920 days and the sixth test, the last, was performed after 1,300 days. Statistical examination of the difference between the rise of D.Q. of the control twins and that of the group supplemented with the amino acids revealed that D.Q. of the supplemented twins rose significantly higher than that of the control twins $(P<0.01)$ (Table 4$)$. In the fourth test (after 780 days) the D.Q. seemed to decrease significantly as compaired with the other general results of the test (Table 4). This phenomenon 
could be due to the stress caused by taking movie film during the examination. Case 2 showed a distinct rise in D.Q. at the second test (after 300 days). This remarkable rise in D.Q. was due to especially arise in the score of learning capacity after supplementation. As seen in Table 4, the increase of D.Q. was more prominent in the early stage of supplementation than in the later stage in most cases except Case 6 where the subjects were older than 3 years when the supplementation of lysine-threonine started. The effects of supplementation on D.Q. were the least in Case 6, even after administration for 1,300 days, compared with the other cases in Table 4. Measurement to ascertain the effect of the supplementation on I.Q. was performed in the fifth and the sixth tests and the effect was unclear in both the experimental and the control twins.

\section{DISCUSSION}

Malnutrition during infancy leads to high infant mortality and small physical size. Infection in malnutrition accelerates these phenomena (2). Many children were undernourished, being smaller and in poorer physical conditions than the control subjects. However, children living in the undernourished areas of North Japan, the only remaining areas suitable for this kind of experiment should not be considered examples of severe forms of protein-calorie malnutrition. It has hitherto been said that early malnutrition may cause permanent or irreversible mental retardation in human beings $(8-12)$ and also that socioeconomic environmental factors might definitely influence the development of brain function.

While severe malnutrition may lead to intellectual impairment, the existence of a direct relationship between moderate malnutrition and intelligence is still unknown. This is because both nutrition and intelligence are associated with various social factors which are very important in both functions $(13,14)$. However, our experimental data on monozygotic twins showed clearly that nutritional improvement can play an important role as one of various complicated factors associated with mental development.

One cannot predict from the present results whether these phenomena will be permanent or irreversible. During the past several years, studies of the electrophysiology on the brain has advanced to the extent that it can be assessed by computer programs following the presentation of stimuli of visual, auditory and E.E.G. analysis (15). Although these methods, including auditory-E.E.G. and E.E.G. analysis, were applied in the present study, no significant results were obtained. The most commonly used measure with respect to general intellectual ability is I.Q. or the intelligence score. In the present experiment, the D.Q. was used in the earlier age period and the I.Q. was used later as seen in Table 4.

In our study, special care was taken that:

1. Infants be monozygotic twins residing in a certain undernourished area and that their age by younger than 3 years to enable reliable use of the D.Q. test. 
2. There not be a wide variation and fluctuation in parent-child and brothersister relationships, physical conditions or socioeconomic situation during the experimental period.

3. The D.Q. and I.Q. examiner not be informed which child was chosen as the experimental subject and which the control.

Though it was extremely difficult, these tests were performed as accurately as possible under the above-mentioned experimental conditions. In short, our experiment in the area of mild-moderate protein-calorie malnutrition suggests that the application of these D.Q. tests has been useful for evaluation of mental function, complementing anthropometrical measurement for evaluation of the nutritional status of children $(16,17)$.

The authors wish to thank the chairmen and members of the Malnutrition Panels of the U.S.-Japan Cooperative Medical Science Program.

\section{REFERENCES}

1) Cravioto, J., de Licardie, E. R., and Birch, H. G., Pediatrics, 38, 319 (1966).

2) SCRimshaw, N. S., Amer. J. of Cl. Nutrition, 20, 493 (1967).

3) Chase, H. P., Nutrition and Gastroenterology Symposium 1. Undernutrition and Mental Development, XIII International Congress of Pediatrics, held at Vienna, Sept. 1971.

4) WinicK, M., Pediatrics, 74, 667 (1969).

5) Tamura, E., Matsuno, N., Nakatsu, M., Nitzeki, S., Wako, H., and Hatakeyama, T., Report of the Research Committee of Essential Amino Acids (in Japanese), 33, 12 (1967).

6) Ushijma, Y., Kida, I., Moriwaki, K., and Irisawa, T., Psychological Tests of Mental Development of Infant and Child, Kaneko-shobo, Tokyo (1969).

7) TANAKA, K., Tanaka-Binet's Intelligence Test, Nippon Bunka Kagakusha, Tokyo (1954).

8) Benton, J. W., Mosen, H. W., Dodge, P. R., and Speils Carr, A. B., Pediatrics, 38, 801 (1968).

9) Culley, W. J. and Lineferger, R. O., J. Nutrition, 96, 375 (1968).

10) Guthrie, H. A. and Brown, M. L., J. Nutrition, 94, 419 (1967).

11) Case, H. P., Dossey, J., and Mckhann, G. M., Pediatrics, 40, 551 (1967).

12) Widdowson, E. M., Dickerson, J. W. T., and McCance, R. A., Brit. J. Nutrition, 14, 457 (1960).

13) Winick, M. and Hoble, A., J. Nutrition, 89, 300 (1966).

14) Kallen, D. J., J. of Amer. Med. Association, 215, 64 (1971).

15) Clarks, A. D. B., J. Child Psychol., 13, 103 (1972).

16) Wako, H., Psychomotor cognitive data, International symposium on criteria and methodology for assessment of nutritional status, held at Tokyo, Nov. 1970.

17) Orso, T., Amino acid fortification of protein foods, The M.I.T. Press, Massachusetts Institute of Technology, Cambridge, Massachusetts, p. 205-219 (1969). 